\title{
Soybean Flour Improves Fatty Acid Profile and Decreases Hepatic Triglyceride Deposition in Rats Fed with Normocaloric and Hypercaloric Diet
}

\author{
Gabriela S. Razzeto1, Viviana R. Lucero López¹, Carlos A. Marra², Luis A. Scardapane1, \\ Nora L. Escudero', María S. Gimenez ${ }^{1 *}$ \\ ${ }^{1}$ Department of Biochemistry and Biological Sciences, Faculty of Chemistry, Biochemistry and Pharmacy, \\ National University of San Luis, San Luis, Argentina \\ ${ }^{2}$ INIBIOLP, CONICET-UNLP, Faculty of Medical Sciences, National University of La Plata, La Plata, Argentina \\ Email: ${ }^{*}$ marisofigime44@gmail.com
}

Received 13 August 2015; accepted 26 October 2015; published 29 October 2015

Copyright (C) 2015 by authors and Scientific Research Publishing Inc.

This work is licensed under the Creative Commons Attribution International License (CC BY). http://creativecommons.org/licenses/by/4.0/

c) (i) Open Access

\section{Abstract}

This study investigated the effects of replacing casein with soy flour on the fatty acids profile and triglycerides metabolism in the liver of rats that were previously fed with normocaloric and hypercaloric diets based on casein. Wistar male rats were used; one group was fed with control diet (AIN-93) and another with hypercaloric diet (AIN-93 with $34.15 \%$ sucrose, $42 \%$ fat calories) for 9 weeks. Each group was then divided into two subgroups and casein was replaced with soybean in one of them, obtaining CC (control casein), CS (control soy), HC (hypercaloric casein) and HS (hypercaloric soy), which were fed for 6 weeks. We measured triglycerides in serum, and triglycerides, total lipids, fatty acids profile, the expression of apolipoprotein B (Apo B), acetyl-CoA carboxylase (ACC), fatty acid synthase (FAS), sterol-regulatory element-binding protein 1c (SREBP1c), mitochondrial glycerol-3-phosphate acyltransferase (mGPAT), diacylglycerol acyltransferase 2 (DGAT-2), carnitine palmitoyltransferase 1 (CPT-1) and peroxisome proliferator-activated receptors alpha (PPAR $\alpha$ ) in liver. Histological studies were also performed. When comparing HS vs. $\mathrm{HC}$, a positive effect of soybean flour on hepatic triglycerides deposits was found, possibly through the reduction in DGAT-2 expression $(P<0.01)$ and the increase in Apo $B(P<0.001)$ expression. Soybean flour also decreased fat deposits in control diets when compared with casein, decreasing the DGAT-2 ( $\mathrm{P}<0.001)$ expression and increasing Apo B $(\mathrm{P}<0.001), \mathrm{CPT}-1(\mathrm{P}<0.05)$ and PPAR $\alpha$ $(P<0.01)$ expressions. Both soy diet subgroups increased unsaturated fatty acids respect to casein diets $(P<0.01)$. Hepatocytes showed few lipid droplets in HS, whereas a fat deposit in HC was ob-

\footnotetext{
"Corresponding author.
}

How to cite this paper: Razzeto, G.S., López, V.R.L., Marra, C.A., Scardapane, L.A., Escudero, N.L. and Gimenez, M.S. (2015) Soybean Flour Improves Fatty Acid Profile and Decreases Hepatic Triglyceride Deposition in Rats Fed with Normocaloric and Hypercaloric Diet. Food and Nutrition Sciences, 6, 1245-1257. http://dx.doi.org/10.4236/fns.2015.614130 
served. These results suggest that replacing casein with soybean flour in normocaloric and hypercaloric diets reduces triglycerides and improves fatty acids profile in rat liver.

\author{
Keywords
}

\author{
Soybean Flour, Normocaloric and Hypercaloric Diets, Fatty Acids, Triglyceride Metabolism, Rat \\ Liver
}

\title{
1. Introduction
}

It is known that diets with a high caloric content induce the development of obesity, glucose intolerance and hyperlipidemia [1]. These conditions predispose towards cardiovascular diseases, ischemic and cerebral vascular accidents, and peripheral vascular pathologies, which constitute the main cause of death worldwide. On the other hand, the Mediterranean diet, consisting of whole grains, fruits and vegetables, has been associated with lower incidence and prevalence of these diseases [2].

Recently, there has been a growing interest in promoting the use of natural food of vegetable origin due to its nutraceutical effects. Several studies in animals and humans have confirmed that diets based on soybean (Glycine max) have a significant impact on health, especially on the prevention of cardiovascular diseases, due to their hypolipemic action. Positive soybean effects have been mainly attributed to its protein composition [3], as well as to its isoflavones content, in particular genistein and daidzein [4].

A high dietary fat intake, in addition to an excessive caloric intake, contributes to the development of hepatic steatosis [5]. This is a common disease and a clear sign of lipotoxicity, attributable in part to an accelerated lipogenesis and the slow oxidation of fatty acids. Hepatic lipid metabolism is partially controlled by the transcription factors known as sterol regulatory element binding proteins (SREBPs) and peroxisome proliferator-activated receptors (PPARs). These transcription factors have different isoforms; in the liver, SREBP-1c and PPAR $\alpha$ are the predominant forms.

SREBP-1c stimulates transcription of fatty acid biosynthesis genes such as acetyl-CoA carboxylase (ACC) and fatty acid synthase (FAS) [6], and is activated in response to insulin [7]. In contrast, PPAR $\alpha$ regulates genes involved in hepatic fatty acid oxidation [8], for example carnitine palmitoyltransferase 1 (CPT-1), an enzyme which regulates the fatty acid $\beta$-oxidation in the mitochondria.

Most studies on soybean use it as a protein concentrate or protein isolate. Considering that soy is a very important part of the diet in many cultures and that it is consumed as a whole grain, we decide to work with soybean flour. The aim of this study was to perform a biochemical-molecular and histological study to see if soybean flour modified the triglyceride metabolism and the fatty acids profile in the liver of male Wistar rats that were previously fed with normocaloric and hypercaloric casein diets.

\section{Materials and Methods}

\subsection{Experimental Design}

Twenty four Wistar male rats (Romanelly, Buenos Aires, Argentina), 21 days old and weighting $36.21 \pm 2.30 \mathrm{~g}$, were kept in individual cages at $25^{\circ} \mathrm{C}$ and exposed to $12 \mathrm{~h}$ light: dark cycles, with food and water ad-libitum. The animals were subjected to a 10 day adaptation period with a diet prepared according to recommendations of the American Institute of Nutrition 1993 (the AIN-93G diet) [9]. Subsequently, they were separated into two groups: one group was kept with the AIN-93G diet, control casein (CC); and the other group hypercaloric casein (HC) was subjected to an hypercaloric diet, both for 9 weeks. The hypercaloric diets contained $341.4 \mathrm{~g} \cdot \mathrm{Kg}^{-1} \mathrm{su}-$ crose and $42 \%$ of calories from fat [10]. After this period, AIN-93G diet was replaced by AIN-93M diet [9], and each group was divided into two subgroups, replacing casein by soy in one of them. Therefore, we ended up with a total of 4 subgroups: control casein (CC), control soy (CS), hypercaloric casein (HC) and hypercaloric soy (HS). Rats were fed with the respective diet for 6 weeks (Figure 1). At this time we believe that there is a lipid turnover efficient. The animals were sacrificed $12 \mathrm{~h}$ after the last feeding and blood was collected and 
processed for serum. Liver and, epididymal and perirenal fat were extracted, weighed, and stored at $-70^{\circ} \mathrm{C}$ for subsequent analyses. Food intake and body weight were recorded every 3 days. The ingredients of each diet are shown in Table 1. Casein was purchased from Milkaut (Santa Fe, Argentina). Casein composition (pasteurized skim milk) was: total protein concentrated by ultracentrifugation: $800 \mathrm{~g} \cdot \mathrm{Kg}^{-1}$, lipids $30 \mathrm{~g} \cdot \mathrm{Kg}^{-1}$. Soybean flour was adquirid from $\mathrm{La}$ esquina de las flores group (Buenos Aires, Argentina). Soybean flour composition was: protein $366.6 \mathrm{~g} \cdot \mathrm{Kg}^{-1}$, lipids $236.6 \mathrm{~g} \cdot \mathrm{Kg}^{-1}$, carbohydrates $233.3 \mathrm{~g} \cdot \mathrm{Kg}^{-1}$, fiber $133.3 \mathrm{~g} \cdot \mathrm{Kg}^{-1}$, (prior heat treatment).

All studies involving experimental animals were conducted in accordance with national and institutional guidelines for the protection of animal welfare. The study was approved by the Animal Care Committee of the National University of San Luis.

\subsection{Serum Parameters}

Triglycerides were determined by the enzymatic method using commercial kits (Wiener Laboratories S.A.I.C. Rosario-Argentina. A.N.M.A.T. Registered product Cert. No. 3803/00).

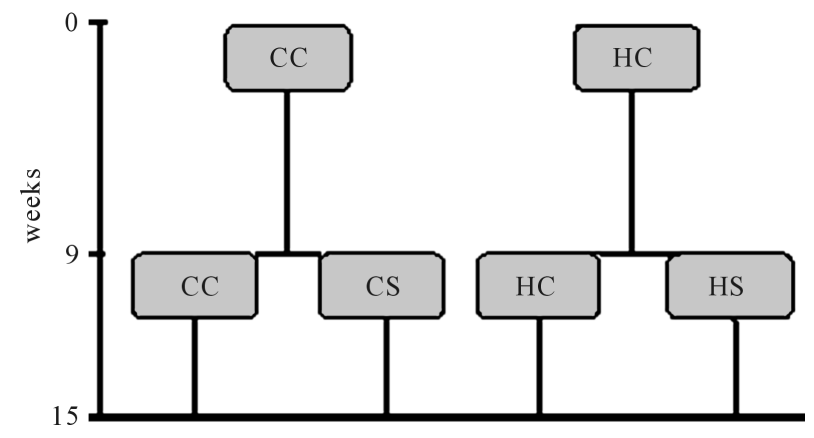

Figure 1. Experimental design. CC, control casein; CS, control soy; HC, hypercaloric casein; HS, hypercaloric soy.

Table 1. Composition of the experimental diets.

\begin{tabular}{|c|c|c|c|c|c|c|}
\hline \multirow{2}{*}{$\begin{array}{l}\text { Ingredients } \\
\left(\mathrm{g} \cdot \mathrm{Kg}^{-1}\right)\end{array}$} & \multicolumn{6}{|c|}{ Groups } \\
\hline & $\mathrm{CC}^{*}$ & $\mathrm{HC}^{*}$ & $\mathrm{CC}^{\dagger}$ & $\mathrm{CS}^{\dagger}$ & $\mathrm{HC}^{\dagger}$ & $\mathrm{HS}^{\dagger}$ \\
\hline Cornstarch & 397.49 & 139.00 & 465.69 & 389.33 & 200.00 & 135.00 \\
\hline Protein sources ${ }^{\mathrm{a}}$ & 212.50 & 212.50 & 150.00 & 327.33 & 150.00 & 327.33 \\
\hline Dextrinized cornstarch & 119.50 & - & 145.00 & 127.67 & - & - \\
\hline Sucrose & 100.00 & 341.46 & 100.00 & 100.00 & 341.46 & 341.46 \\
\hline Animal fat & - & 136.50 & - & - & 168.38 & 139.09 \\
\hline Soybean oil & 70.00 & 70.00 & 40.00 & - & 40.00 & - \\
\hline Fiber & 50.00 & 50.00 & 50.00 & 6.37 & 50.00 & 6.37 \\
\hline Mineral mix & 35.00 & 35.00 & 35.00 & 35.00 & 35.00 & 35.00 \\
\hline Vitamin mix & 10.00 & 10.00 & 10.00 & 10.00 & 10.00 & 10.00 \\
\hline L-Cystine & 3.00 & 3.00 & 1.80 & 1.80 & 1.80 & 1.80 \\
\hline Choline bitartrate & 2.50 & 2.50 & 2.50 & 2.50 & 2.50 & 2.50 \\
\hline Tert-butylhydroquinone & 0.014 & 0.014 & 0.008 & 0.008 & 0.008 & 0.008 \\
\hline
\end{tabular}

CC, control casein; HC, hypercaloric casein; CS, control soy; HS, hypercaloric soy. *AIN 93G; ${ }^{\dagger} \mathrm{AIN} 93 \mathrm{M}$; ${ }^{\mathrm{a} P r o t e i n}$ sources: casein, $80 \mathrm{~g}$ total protein per $100 \mathrm{~g}$ of milk; soybean flour, $36.66 \mathrm{~g}$ protein per $100 \mathrm{~g}$ of soybean flour. 


\subsection{Hepatic Lipids Determinations}

Lipids were extracted from liver tissue $(300 \mathrm{mg})$ in a hexane/isopropanol mixture $(3: 2 \mathrm{v} / \mathrm{v})$, containing butylated hydroxytoluene as antioxidant [11]. Total lipids were determined by dry weight [12]. Lipids were resuspended in hexane, and aliquots of the extracts were placed on thin-layer chromatography (TLC) plates coated with silica gel G, using hexane/diethyl ether/acetic acid $(80: 20: 1, \mathrm{v} / \mathrm{v} / \mathrm{v})$ as the running solvent, for the separation of the different lipids. Triglycerides were detected by exposing the plates to iodine vapor; they were scraped off and used for the determination of triglycerides [13]. Proteins were determined by the Biuret method [14], with bovine serum albumin as standard (BSA or Fraction V) acquired from Sigma-Aldrich (St. Louis, Missouri, United States).

Capillary gas-liquid chromatography (c-GLC) of the fatty acid methyl esters (FAME) was performed according to Marra and de Alaniz [15]; although in this case, we used a capillary column (Omegawax 250, from Bellefonte, Supelco, PA) mounted on a Hewlett Packard HP 6890 Series GC System Plus (Avondale, PA), equipped with a terminal computer integrator and a data station. A standard procedure for a single-step preparation of dimethyl disulfide adducts of the fatty acids was performed according to Yamamoto et al. [16].

\section{4. mRNA Expression by RT-PCR Analyses}

The relative mRNA quantities of apolipoprotein B (Apo-B), acetyl-CoA carboxylase (ACC), fatty acid synthase (FAS), mitochondrial glycerol-3-phosphate acyltransferase (mtGPAT), diacylglycerol acyltransferase 2 (DGAT-2), sterol-regulatory element-binding protein $1 \mathrm{c}$ (SREBP-1c), carnitine palmitoyltransferase 1 (CPT-1) and peroxisome proliferator-activated receptors alpha (PPAR $\alpha$ ), were determined by reverse transcription polymerase chain reaction (RT-PCR).

Total RNA from the liver was isolated using TRIZOL Reagent (Invitrogen, Buenos Aires, Argentina), and cDNA synthesis was performed using 200 IU of Moloney Murine Leukemia Virus Reverse Transcriptase (Invitrogen/life Technologies, Buenos Aires, Argentina) and random hexamer primers. cDNA was amplified for 5 min at $94^{\circ} \mathrm{C}$ followed by cycles of $1 \mathrm{~min}$ of denaturation at $94^{\circ} \mathrm{C}, 1 \mathrm{~min}$ of annealing at primers specific temperatures and $1 \mathrm{~min}$ of elongation at $72^{\circ} \mathrm{C}$, followed by a final extension at $72^{\circ} \mathrm{C}$ for $5 \mathrm{~min}$.

The sequences of the different primers and sizes of the PCR products are shown in Table 2.

The PCR products were analyzed on $2.5 \%$ agarose gels containing $0.008 \%(\mathrm{v} / \mathrm{v})$ of fluorescent nucleic acid gel stains, and photographed under UV transillumination. The intensity of each band was measured using the NIH Image software Scion. The relative abundance of each target band was then normalized according to the housekeeping gene $\beta$-actin, calculated as the ratio of the intensity values of each target product to that of $\beta$-actin, and reported in arbitrary units (AU).

\subsection{Morphological Study}

Histological analysis of liver samples was performed with light microscopy. Pieces of liver were excised and immediately fixed in Bouin's liquid. All sections were obtained from the same region of the liver for effective comparison. Sections were stained with hematoxylin-eosin and photographs were taken using a Leitz Dialux optical microscope equipped with a Leica camera $(400 \times)$.

\subsection{Statistical Analysis}

The data were expressed as means \pm standard deviations. The results were analyzed using one-way analysis of variance (ANOVA), provided by the multiple comparison of Tukey-Kramer means test. A probability of 0.05 or less indicates significant difference [17]. The following comparisons between groups were performed: CS vs.CC, HS vs. HC and HS vs. CS.

\section{Results}

\subsection{Growth Variables and Tissue Weights in Rats}

Food intake, body weight gain, liver weight, and epididymal and perirenal fat in rats are shown in Table 3. Food intake did not vary among the different groups. Respect to body weight gain, it was observed that CS rats gained less weight than those from the $\mathrm{CC}$ group $(\mathrm{P}<0.01)$ and similar behavior occurred when comparing $\mathrm{HS}$ vs. HC 
Table 2. Sequences of the gene-specific primers and sizes of the PCR products.

\begin{tabular}{cccc}
\hline \multirow{2}{*}{ Primers } & \multicolumn{2}{c}{ Sequences } & Size (bp) \\
\cline { 2 - 4 } Apo-B & TACCTCCGGCAGCTCCATTCC & Ant'-3') $\left(5^{\prime}\right.$-3') & 340 \\
ACC & ACTCCAGGACAGCACAGATC & TGCGCTTCCTGCTCTTGCTGTT & 535 \\
FAS & GTTTGATGGCTCACACACCT & TACACTCACTCGAGGCTCAG & 515 \\
SREBP-1c & GGAGCCATGGATTGCACATT & AGGAAGGCTTCCAGAGAGGC & 193 \\
mtGPAT & TGATCAGCCAGGAGCAGCTG & AGACAGTATGTGGCACTCTC & 508 \\
DGAT-2 & GGAGGCCACCGAAGTTAGCAAGAA & AGCCCCCAGGTGTCAGAGGAGAAG & 453 \\
CPT-1 & TATGTGAGGATGCTGCTTCC & CTCGGAGAGCTAAGCTTGTC & 629 \\
PPAR $\alpha$ & TCAGGGTACCACTACGGAGTTCA & CCGAATAGTTCGCCGAAAGA & 106 \\
$\beta$-actin & CGTGGGCCGCCCAGGCACCA & TTGGCCTTAGGGTTCAGAGGG & 243 \\
\hline
\end{tabular}

Apo-B, apolipoprotein B; ACC, acetyl-CoA carboxylase; FAS, fatty acid synthase; SREBP-1c, sterol-regulatory element-binding protein 1c; mtGPAT, mitochondrial glycerol-3-phosphate acyltransferase; DGAT-2, diacylglycerol acyltransferase 2; CPT-1, carnitine palmitoyltransferase 1; PPAR $\alpha$, peroxisome proliferator-activated receptors alpha.

Table 3. Effects of diets on growth variables and tissue weights in rats.

\begin{tabular}{ccccc}
\hline \multirow{2}{*}{ Parameters } & \multicolumn{3}{c}{ Groups } \\
\cline { 2 - 5 } & $\mathrm{CC}(n$ 6) & $\mathrm{CS}(n$ 6) & HC $(n$ 6) & HS $(n$ 6) \\
\hline Food intake (g/120d) & $1504.52 \pm 37.13$ & $1594.35 \pm 69.86$ & $1535.17 \pm 50.28$ & $1605.02 \pm 73.21$ \\
Body weight, gain g/120d $\mathrm{d}^{\mathrm{a}}$ & $351.37 \pm 10.61$ & $288.78 \pm 16.09 \bullet$ & $386.12 \pm 32.23$ & $342.91 \pm 25.91^{\circ *}$ \\
Liver weight (g) & $11.07 \pm 0.67$ & $9.11 \pm 0.47 \bullet$ & $11.94 \pm 0.80$ & $10.24 \pm 0.73^{\circ \circ}$ \\
Liver (g/100g body wt.) & $2.77 \pm 0.24$ & $2.92 \pm 0.11$ & $2.75 \pm 0.05$ & $2.75 \pm 0.20$ \\
Epididymal fat (g/100g body wt.) & $0.72 \pm 0.10$ & $0.65 \pm 0.10$ & $1.40 \pm 0.10$ & $1.10 \pm 0.16^{0^{* *}}$ \\
Perirenal fat (g/100g body wt.) & $1.46 \pm 0.11$ & $0.87 \pm 0.15 \bullet$ & $1.90 \pm 0.14$ & $1.25 \pm 0.30^{\circ \circ}$ \\
\hline
\end{tabular}

Values are means $\pm \mathrm{SD}(n=6)$. Analyzed by one-way analysis of variance (ANOVA) followed by Tukey multiple comparison test. $\bullet$ CS vs. CC: $\bullet \cdot P<$ 0.01 ; ${ }^{\circ} \mathrm{HS}$ vs. HC: ${ }^{\circ} \mathrm{P}<0.05,{ }^{\circ} \mathrm{P}<0.01$; ${ }^{*} \mathrm{HS}$ vs. CS: ${ }^{*} \mathrm{P}<0.05,{ }^{* *} \mathrm{P}<0.01$. CC, control casein; CS, control soy; HC, hypercaloric casein; HS, hypercaloric soy. ${ }^{\mathrm{a}}$ Final weight minus initial weight.

$(\mathrm{P}<0.05)$, furthermore animals fed with HS diet showed a higher increment of body weight gain than those fed with CS diets $(\mathrm{P}<0.05)$. Animals fed with soy flour showed lower liver weight than those fed with casein diets, in both control and hypercaloric diets $(\mathrm{P}<0.01)$. Rats fed with HS diet showed a decrease in the relative epididymal fat weight (per $100 \mathrm{~g}$ of body weight) when compared to HC group $(\mathrm{P}<0.05)$, also HS showed an increase when compared to the respective control $(\mathrm{P}<0.01)$. Regarding the perirenal fat, animals fed with soy flour showed decreased relative perirenal fat weights (per $100 \mathrm{~g}$ of body weight) compared to those fed with casein diets $(\mathrm{P}<0.01)$.

\subsection{Triglycerides in Serum, and Triglycerides and Total Lipids in Liver}

Triglycerides in serum, and triglycerides and total lipids in liver, are shown in Figure 2. Serum triglycerides showed no differences between groups. Regarding the hepatic triglycerides content, both control and hypercaloric soy flour diets showed significantly lower triglycerides than casein diets, $(\mathrm{P}<0.05)$ and $(\mathrm{P}<0.01)$, respectively, and was observed a significant increased when comparing HS vs. CS $(\mathrm{P}<0.05)$. Variations in the total lipids content followed a relation with the hepatic triglyceride deposits, being lower in soy flour diets compared to casein diets, $\mathrm{CS}$ vs. $\mathrm{CC}(\mathrm{P}<0.001)$ and HS vs. $\mathrm{HC}(\mathrm{P}<0.01)$, with an increase in HS group compared to CS group $(\mathrm{P}<0.001)$. 


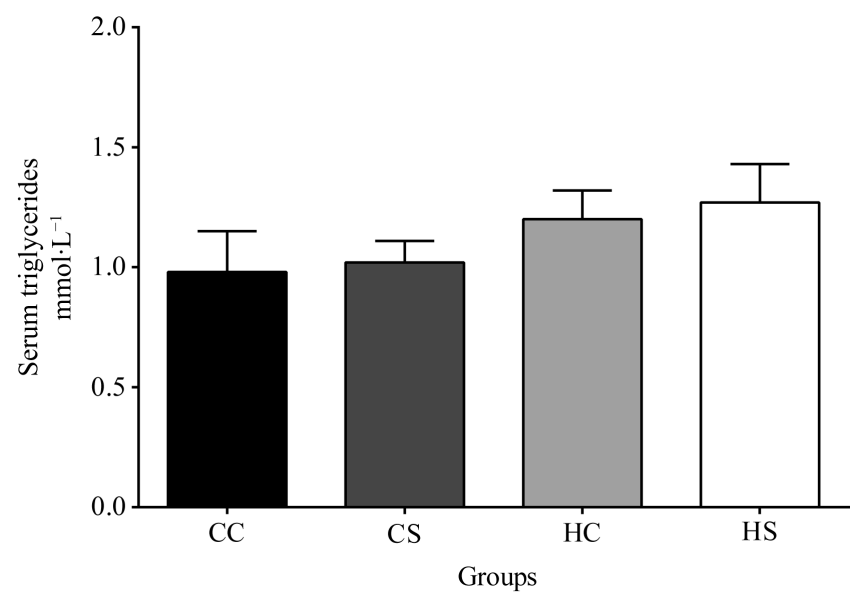

(a)

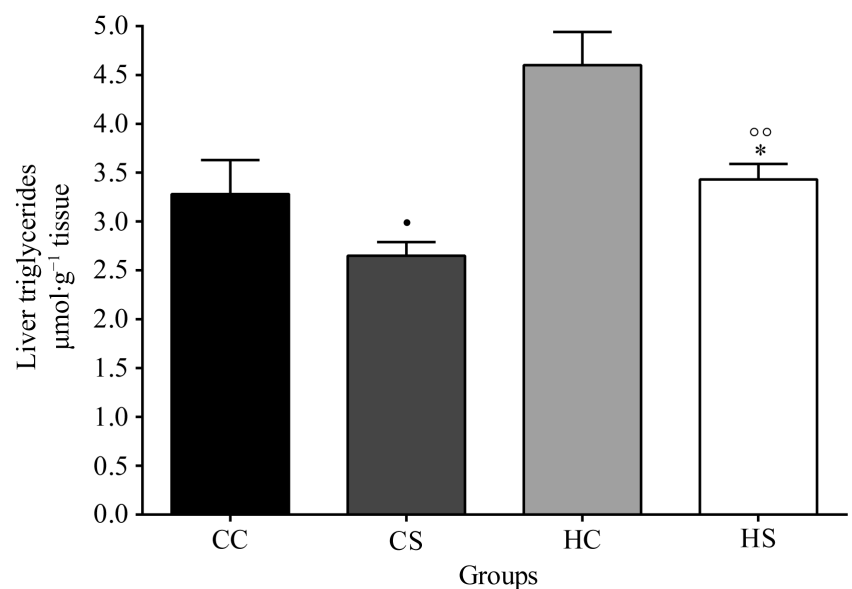

(b)

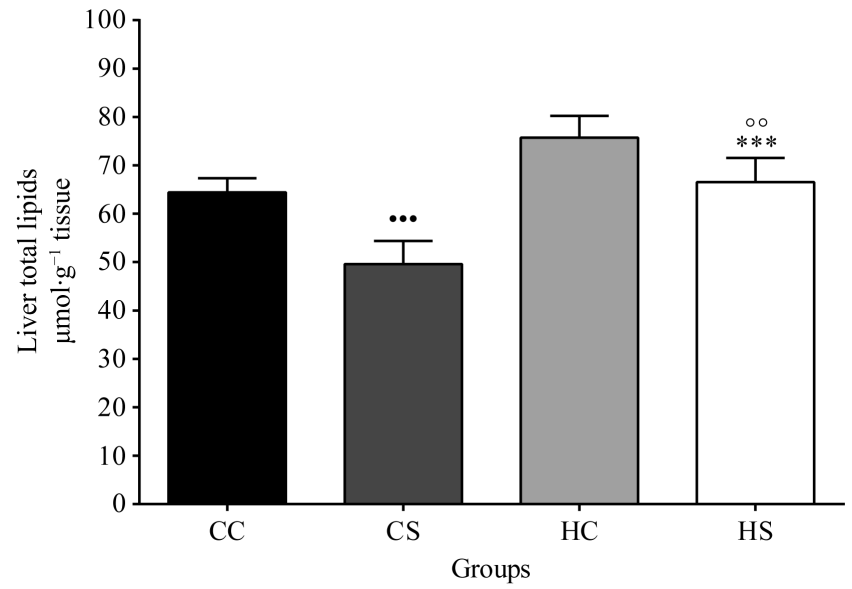

(c)

Figure 2. Effects of diets on (a) triglycerides in serum, and (b) triglycerides and (c) total lipids in liver. Values are means \pm SD $(n=6)$. Analyzed by one-way analysis of variance (ANOVA) followed by Tukey multiple comparison test. $\cdot$ CS vs. CC: $\bullet P<$ $0.05 ; \cdots \mathrm{P}<0.001 ;{ }^{\circ} \mathrm{HS}$ vs. HC: ${ }^{\circ \circ} \mathrm{P}<0.01 ;{ }^{*} \mathrm{HS}$ vs. $\mathrm{CS}:{ }^{*} \mathrm{P}<$ $0.05 ;{ }^{* * *} \mathrm{P}<0.001$. CC, control casein; CS, control soy; HC, hypercaloric casein; HS, hypercaloric soy. 


\section{3. mRNA Levels of Enzymes and Transcription Factors Involved in Lipogenesis and Fatty Acid Oxidation in Liver Rat}

Table 4 shows the mRNA levels of Apo-B, lipogenic enzymes and SREBP-1c. Soy flour significantly increased the expression of Apo-B gene in soy diets when compared to casein, CS vs. CC and HS vs. HC $(\mathrm{P}<0.001)$. In order to find out the variations in the lipogenic enzymes expression and its regulation, we determined the expression of ACC, FAS, mtGPAT, DGAT-2 and SREBP-1c. There were no significant differences in the expression of ACC, FAS and SREBP-1c among the groups. The mtGPAT expression was decreased in HS group when compared to CS $(\mathrm{P}<0.001)$. Soy flour significantly decreased DGAT-2 gene expression in soy diets groups when compared to casein, $\mathrm{CS}$ vs. $\mathrm{CC}(\mathrm{P}<0.001)$ and HS vs. $\mathrm{HC}(\mathrm{P}<0.01)$. mRNA levels of genes involved in fatty acid oxidation are also shown in Table 4. The expressions of CPT-1 and PPAR $\alpha$ in rats fed with CS diet were significantly higher than those in rats fed with $\mathrm{CC}$ diet, with $(\mathrm{P}<0.05)$ and $(\mathrm{P}<0.01)$, respectively. The mRNA abundance of both transcripts was significantly lower in rats fed with HS diet than in animals fed with CS diet, $(\mathrm{P}<0.05)$ and $(\mathrm{P}<0.001)$, respectively.

\subsection{Fatty Acids Composition in Rat Liver}

The analysis of the fatty acids profiles in rat liver (Table 5), showed that replacing the casein diets by a vegetable protein, such as soybean flour, induces an increase of unsaturated fatty acids and a decrease of saturated ones $(\mathrm{P}<0.01)$, even with the hypercaloric diets. There was a clear decrease in lauric, myristic and palmitic acids in liver of rats fed with soy. The unsaturated: saturated fatty acids ratio (unsat: sat), increased in both soy diets compared with casein. The total omega-6 polyunsaturated fatty acids (PUFA n-6) was significantly higher in the $\mathrm{CS}$ and HS groups compared to the casein groups $(\mathrm{P}<0.01)$. Similar behavior was observed in total omega-3 polyunsaturated fatty acids (PUFA $n-3$ ), and a lower $n-6: n-3$ ratio was observed in soy groups compared to casein groups.

\subsection{Histological Studies}

Liver histological studies showed that the parenchyma of the CC group rats, had hepatocytes infiltrated by fatty deposits; while in the parenchyma of the CS group rats, fatty deposits were rare and localized, and the hepatocytes had a normal appearance with lipid droplets in the cytoplasm. The parenchyma of the HC group rats showed widely distributed fatty deposits, occupying most of the cytoplasm, which had a spongy appearance; however in HS group, the hepatocytes had a normal histoarchitecture with few lipid droplets (Figure 3).

Table 4. Effects of diets on mRNA levels of enzymes and transcription factors involved in lipogenesis and fatty acid oxidation in liver rat.

\begin{tabular}{|c|c|c|c|c|}
\hline \multirow{2}{*}{ Parameters (AU) } & \multicolumn{4}{|c|}{ Groups } \\
\hline & $\mathrm{CC}(n 6)$ & $\operatorname{CS}(n 6)$ & $\mathrm{HC}(n 6)$ & HS ( $n$ 6) \\
\hline Apo B & $0.75 \pm 0.04$ & $1.04 \pm 0.05 \cdots$ & $0.80 \pm 0.03$ & $1.09 \pm 0.04^{\circ 0 \circ}$ \\
\hline ACC & $0.34 \pm 0.03$ & $0.35 \pm 0.04$ & $0.32 \pm 0.02$ & $0.34 \pm 0.04$ \\
\hline FAS & $0.85 \pm 0.05$ & $0.99 \pm 0.08$ & $0.82 \pm 0.07$ & $0.82 \pm 0.07$ \\
\hline SREBP-1c & $1.49 \pm 0.14$ & $1.67 \pm 0.10$ & $1.57 \pm 0.12$ & $1.59 \pm 0.18$ \\
\hline mtGPAT & $1.00 \pm 0.08$ & $0.93 \pm 0.02$ & $0.79 \pm 0.01$ & $0.74 \pm 0.04^{* * *}$ \\
\hline DGAT-2 & $1.06 \pm 0.04$ & $0.80 \pm 0.03 \cdots$ & $0.97 \pm 0.02$ & $0.86 \pm 0.02^{\circ \circ}$ \\
\hline CPT-1 & $0.71 \pm 0.06$ & $0.87 \pm 0.09 \bullet$ & $0.65 \pm 0.03$ & $0.65 \pm 0.06^{*}$ \\
\hline PPAR $\alpha$ & $0.83 \pm 0.04$ & $0.97 \pm 0.01 \bullet \bullet$ & $0.83 \pm 0.03$ & $0.77 \pm 0.03^{* * *}$ \\
\hline
\end{tabular}

Values are means $\pm \mathrm{SD}(n=6)$. Analyzed by one-way analysis of variance (ANOVA) followed by Tukey multiple comparison test. $\bullet \mathrm{CS}$ vs. CC: $\bullet P$ $0.05 ; \bullet \mathrm{P}<0.01, \cdots \mathrm{P}<0.001 ;{ }^{\circ} \mathrm{HS}$ vs. HC: ${ }^{\circ} \mathrm{P}<0.01,{ }^{\circ 0} \mathrm{P}<0.001 ;{ }^{*} \mathrm{HS}$ vs. CS: ${ }^{*} \mathrm{P}<0.05 ;{ }^{* * *} \mathrm{P}<0.001$. CC, control casein; CS, control soy; HC, hypercaloric casein; HS, hypercaloric soy. AU, arbitrary units. Apo-B, apolipoprotein B; ACC, acetyl-CoA carboxylase; FAS, fatty acid synthase; SREBP-1c, sterol-regulatory element-binding protein 1c; mtGPAT, mitochondrial glycerol-3-phosphate acyltransferase; DGAT-2, diacylglycerol acyltransferase 2; CPT-1, carnitine palmitoyltrans ferase 1 ; PPAR $\alpha$, peroxisome proliferator-activated receptors alpha. 
Table 5. Effects of diets on fatty acid composition in rat liver.

\begin{tabular}{|c|c|c|c|c|}
\hline \multirow{2}{*}{$\begin{array}{c}\text { Fatty acids } \\
\left(\mu \mathrm{mol} \cdot \mathrm{mg}^{-1} \text { of total lipids }\right)\end{array}$} & \multicolumn{4}{|c|}{ Groups } \\
\hline & $\mathrm{CC}(n 6)$ & $\operatorname{CS}(n 6)$ & $\mathrm{HC}(n 6)$ & HS ( $n$ 6) \\
\hline $12: 0$ & $0.8 \pm 0.1^{\mathrm{a}}$ & $0.2 \pm 0.1^{\mathrm{b}}$ & $0.9 \pm 0.2^{\mathrm{a}}$ & $0.3 \pm 0.03^{b}$ \\
\hline $14: 0$ & $2.5 \pm 0.1^{\mathrm{a}}$ & $0.5 \pm 0.1^{\mathrm{b}}$ & $3.1 \pm 0.2^{\mathrm{c}}$ & $0.4 \pm 0.02^{\mathrm{b}}$ \\
\hline $15: 0$ & $0.1 \pm 0.03^{\mathrm{a}}$ & $0.1 \pm 0.01^{\mathrm{a}}$ & $0.2 \pm 0.07^{\mathrm{a}}$ & $0.1 \pm 0.06^{\mathrm{a}}$ \\
\hline $16: 0$ & $18.8 \pm 0.7^{\mathrm{a}}$ & $13.2 \pm 0.3^{b}$ & $19.5 \pm 0.5^{\mathrm{a}}$ & $16.1 \pm 0.3^{\mathrm{c}}$ \\
\hline $16: 1 n-7$ & $2.0 \pm 0.1^{\mathrm{a}}$ & $2.5 \pm 0.1^{\mathrm{a}}$ & $2.2 \pm 0.2^{\mathrm{a}}$ & $2.7 \pm 0.2^{\mathrm{a}}$ \\
\hline $16: 1 n-4$ & $0.2 \pm 0.01^{\mathrm{a}}$ & $0.2 \pm 0.05^{\mathrm{a}}$ & $0.3 \pm 0.03$ & $0.1 \pm 0.04$ \\
\hline $17: 0$ & $0.1 \pm 0.02^{\mathrm{a}}$ & $0.2 \pm 0.02^{\mathrm{a}}$ & $0.1 \pm 0.04^{\mathrm{a}}$ & $0.2 \pm 0.03^{\mathrm{a}}$ \\
\hline 18:0 & $29.2 \pm 0.8^{\mathrm{a}}$ & $24.1 \pm 0.8^{\mathrm{b}}$ & $28.5 \pm 0.4^{\mathrm{a}}$ & $23.5 \pm 0.5^{\mathrm{b}}$ \\
\hline $18: 1 n-9$ & $5.3 \pm 0.3^{\mathrm{a}}$ & $6.0 \pm 0.2$ & $5.1 \pm 0.2^{\mathrm{a}}$ & $7.9 \pm 0.3^{b}$ \\
\hline $18: 1 n-7$ & $0.5 \pm 0.2^{\mathrm{a}}$ & $0.8 \pm 0.2^{\mathrm{a}}$ & $0.7 \pm 0.2^{\mathrm{a}}$ & $0.9 \pm 0.2^{\mathrm{a}}$ \\
\hline $18: 2 n-6$ & $17.2 \pm 0.3^{\mathrm{a}}$ & $23.9 \pm 0.4^{\mathrm{b}}$ & $18.0 \pm 0.3^{\mathrm{a}}$ & $27.2 \pm 0.5^{\mathrm{c}}$ \\
\hline $18: 3 n-6$ & $0.3 \pm 0.03^{\mathrm{a}}$ & $0.2 \pm 0.01^{\mathrm{a}}$ & $0.2 \pm 0.04^{\mathrm{a}}$ & $0.2 \pm 0.02^{\mathrm{a}}$ \\
\hline $18: 3 n-3$ & $0.1 \pm 0.03^{\mathrm{a}}$ & $3.1 \pm 0.2^{\mathrm{b}}$ & $0.2 \pm 0.06^{\mathrm{a}}$ & $3.2 \pm 0.1^{\mathrm{b}}$ \\
\hline $20: 0$ & $2.5 \pm 0.2^{\mathrm{a}}$ & $1.1 \pm 0.1^{\mathrm{b}}$ & $2.9 \pm 0.2^{\mathrm{a}}$ & $1.0 \pm 0.2^{\mathrm{b}}$ \\
\hline $20: 1 n-9$ & $1.5 \pm 0.4^{\mathrm{a}}$ & $1.9 \pm 0.2^{\mathrm{a}}$ & $1.6 \pm 0.3^{\mathrm{a}}$ & $2.0 \pm 0.2^{\mathrm{a}}$ \\
\hline $20: 2 n-6$ & $1.6 \pm 0.1^{\mathrm{a}}$ & $0.5 \pm 0.1^{\mathrm{b}}$ & $1.7 \pm 0.2^{\mathrm{a}}$ & $0.7 \pm 0.1^{b}$ \\
\hline $20: 3 n-6$ & $1.5 \pm 0.1^{\mathrm{a}}$ & $3.5 \pm 0.1^{\mathrm{b}}$ & $1.9 \pm 0.2^{\mathrm{a}}$ & $3.4 \pm 0.1^{\mathrm{b}}$ \\
\hline $20: 3 n-9$ & $0.8 \pm 0.1^{\mathrm{a}}$ & Traces $^{\mathrm{b}}$ & $2.2 \pm 0.2^{\mathrm{c}}$ & $0.2 \pm 0.05^{\mathrm{d}}$ \\
\hline $20: 4 n-6$ & $24.3 \pm 0.4^{\mathrm{a}}$ & $33.1 \pm 0.6^{\mathrm{b}}$ & $26.1 \pm 0.5^{\mathrm{a}}$ & $31.0 \pm 0.5^{\mathrm{b}}$ \\
\hline $20: 5 n-3$ & $0.5 \pm 0.1^{\mathrm{a}}$ & $1.5 \pm 0.1^{\mathrm{b}}$ & $0.4 \pm 0.1^{\mathrm{a}}$ & $1.8 \pm 0.1^{\mathrm{b}}$ \\
\hline $22: 4 n-3$ & $0.7 \pm 0.1^{\mathrm{a}}$ & $0.8 \pm 0.1^{\mathrm{a}}$ & $1.3 \pm 0.1^{\mathrm{b}}$ & $2.0 \pm 0.2^{\mathrm{b}}$ \\
\hline $22: 4 n-6$ & $1.1 \pm 0.1^{\mathrm{a}}$ & $1.5 \pm 0.1^{\mathrm{a}}$ & $1.2 \pm 0.1^{\mathrm{a}}$ & $1.6 \pm 0.1^{\mathrm{a}}$ \\
\hline $22: 5 n-3$ & $2.2 \pm 0.1^{\mathrm{a}}$ & $3.4 \pm 0.2^{\mathrm{b}}$ & $2.5 \pm 0.2^{\mathrm{a}}$ & $3.5 \pm 0.1^{\mathrm{b}}$ \\
\hline $22: 5 n-6$ & $0.2 \pm 0.01^{\mathrm{a}}$ & $0.3 \pm 0.01^{\mathrm{a}}$ & $0.3 \pm 0.1^{\mathrm{a}}$ & $0.2 \pm 0.03^{\mathrm{a}}$ \\
\hline $22: 6 n-3$ & $5.3 \pm 0.1^{\mathrm{a}}$ & $7.9 \pm 0.2^{\mathrm{b}}$ & $4.9 \pm 0.1^{\mathrm{a}}$ & $7.5 \pm 0.2^{\mathrm{b}}$ \\
\hline Total unsaturated fatty acid & $65.3 \pm 3.0^{\mathrm{a}}$ & $91.1 \pm 2.9^{\mathrm{b}}$ & $70.8 \pm 2.6^{\mathrm{a}}$ & $96.1 \pm 3.0^{\mathrm{b}}$ \\
\hline Total saturated fatty acid & $54 \pm 2.0^{\mathrm{a}}$ & $39.48 \pm 1.4^{\mathrm{b}}$ & $55.2 \pm 2.0^{\mathrm{a}}$ & $41.6 \pm 1.4^{b}$ \\
\hline Unsatured:satured & 1.20 & 2.30 & 1.28 & 2.31 \\
\hline Total PUFA $n-6$ & $46.2 \pm 1.0^{\mathrm{a}}$ & $63.0 \pm 1.3^{\mathrm{b}}$ & $49.4 \pm 1.4^{\mathrm{a}}$ & $64.3 \pm 1.3^{b}$ \\
\hline Total PUFA $n-3$ & $8.8 \pm 0.4^{\mathrm{a}}$ & $16.7 \pm 0.8^{\mathrm{b}}$ & $9.3 \pm 0.7^{\mathrm{a}}$ & $18.0 \pm 0.7^{\mathrm{b}}$ \\
\hline$n-6: n-3$ ratio & 5.25 & 3.77 & 5.31 & 3.57 \\
\hline
\end{tabular}

Values are means $\pm \mathrm{SD}(n=6)$. Analyzed by one-way analysis of variance (ANOVA) followed by Tukey multiple comparison test. Means in row with different letter differ significantly $(\mathrm{P}<0.01)$. CC, control casein; CS, control soy; HC, hypercaloric casein; HS, hypercaloric soy. PUFA $n-6$, omega- 6 polyunsaturated fatty acids; PUFA $n-3$, omega-3 polyunsaturated fatty acids. 

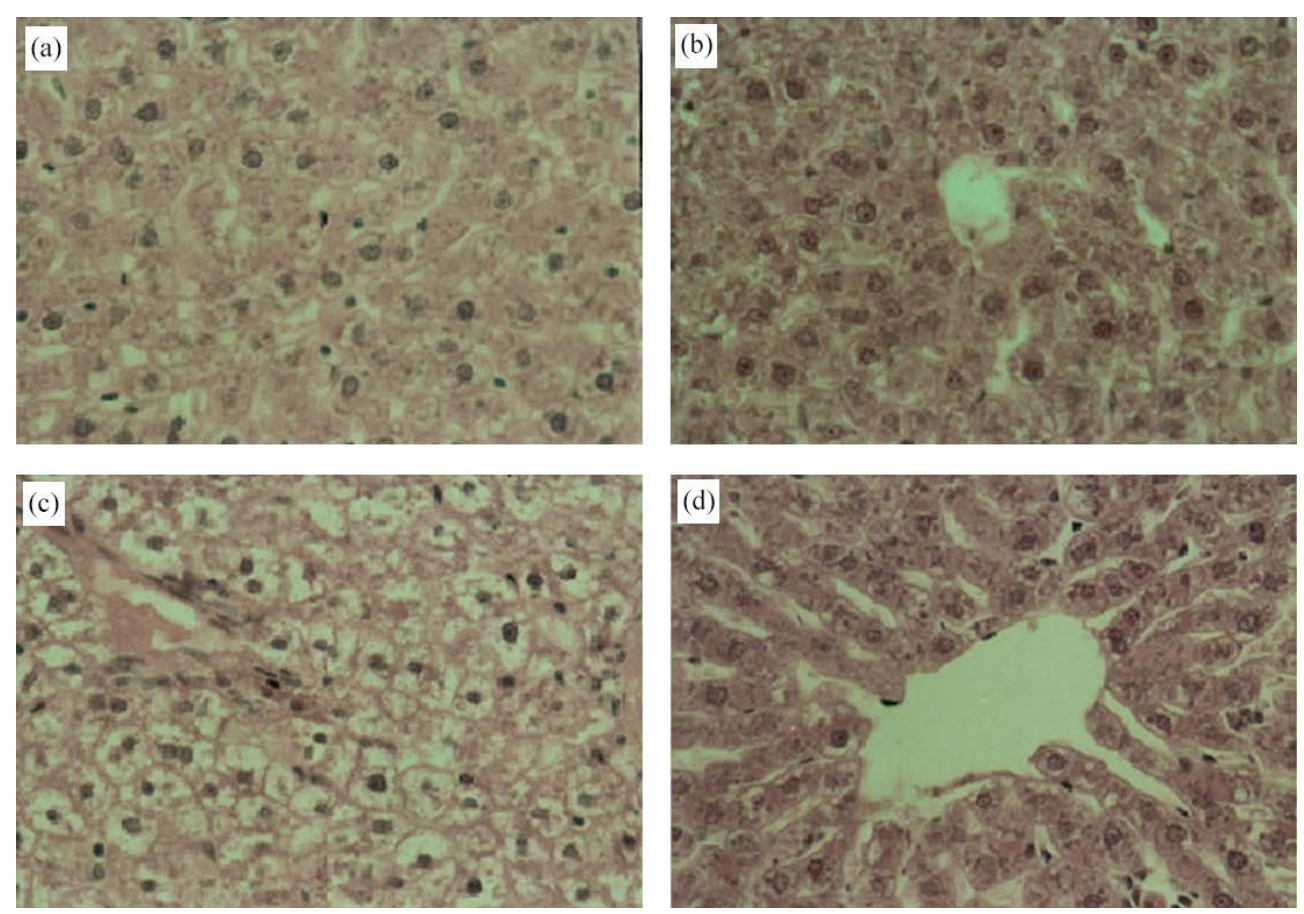

Figure 3. Photomicrographs of the effects of diets on hepatic parenchyma in rats. (a) Parenchyma of rats CC (control casein) group. (b) Parenchyma of rats CS (control soy) group. (c) Parenchyma of rats HC (hypercaloric casein) group. (d) Parenchyma of rats HS (hypercaloric soy) group.

\section{Discussion}

It is known that dietary composition significantly influences the development of certain chronic diseases [18], and that the long term consumption of a diet high in fat accelerates the development of obesity [19]. Numerous investigations indicate that soybean has many nutritional attributes, given by its content of isoflavones, essential amino acids, fibers, poly-unsaturated fatty acids, vitamins and minerals. There are multiple studies on the different mechanisms of action of soy protein and its isoflavones, but there is little literature on the potential effects of soy flour (whole grain) as a possible treatment for to improve lipid metabolism. Considering that soy is consumed essentially in the form of flour or whole grain, we decided to investigate if soybean flour is capable of modifying triglyceride content and fatty acid profile in the rats liver, after were subjected to a casein diet for 9 weeks.

Rats fed with soy diets gained significantly less weight than those fed with casein diets. This difference could be mainly due to the lower body fat content observed, in particular in the epididymal and perirenal fat, as well as a lower liver weight. Al-Dwairi et al. [20] reported that inclusion of soy protein isolate in the diet lowered body fat content, and found that wild type mice fed with soy protein isolate showed significantly reduced weight gains compared to those fed with casein hypercaloric diet. Our results also agree with those obtained by Torre-Villalvazo et al. [21]. On the other hand other components of soybean flour like flavonoids could contribute to less body weight [22]. Furthermore, our results show that soy flour provides more amount of eicosapentaenoic acid (EPA) and docosahexaenoic acid (DHA) than casein. It is know that these fatty acids have anti-obesity effects and reduce body weight [23]. These results suggest that soybean began to decrease fat accumulation caused by the previously administered casein diets.

We found no differences in serum triglycerides levels between rats fed with soy and those fed with casein. The results reported in the literature are controversial, some authors have reported a decrease [24] and others an increase [25], and there are also studies reporting no differences in this parameter [26]. Regarding triglycerides in the liver, we observed less accumulation in rats fed with soy-based diets, and this difference was more significant in the hypercaloric groups. Ascencio et al. [27] found that hepatic triglycerides were reduced by consumption of soy protein or soy protein high fat diets compared with rats fed with casein or casein high fat diets. Thus, we conclude that soybean flour with a protein concentration of $36.66 \%$ protects against hepatic triglyceride de- 
positionin this model, being this effect more marked in the case of hypercaloric groups.

Apo B, an essential structural component of very low density lipoprotein (VLDL) and low density lipoprotein (LDL), must be assembled into lipoprotein particles before being secreted from hepatocytes [28]. The expression of Apo-B increased in soybean diets compared to casein diets, this behavior correlate with hepatic triglycerides levels.

The fact that there were no changes in the expression of the ACC and FAS genes, and the SREBP-1c involved in the fatty acid synthesis, suggests that they probably suffer post transcriptional modifications. However Xiao et $a l$. [29] found that ingestion soy protein isolate decreases plasma TAG level and down-regulates ACC gene expression in the liver. Besides, Shukla et al. [30] observed that isoflavone-poor soy protein isolate alters lipid metabolism by the down-regulation of SREBPs and its target genes in the liver.

Hepatic triglyceride deposits are lower in animals fed with soybean flour. In order to better understand these results, we determined the expression of genes of enzymes involved in the synthesis of triglycerides: mtGPAT and DGAT-2. The decrease of the mtGPAT expression when comparing HS vs. CS, suggests a possible downregulation of the enzyme due to excess fat. Furthermore, an interesting behavior was observed in the expression of DGAT-2 gene, enzyme that catalyzes the final step in the main pathway for hepatic triglycerides synthesis. The lower expression in soybean diets compared to casein diets may be due to the higher content of polyunsaturated fatty acids present in the soy flour. This is in accord with Rustan et al. [31], who demonstrated that diets with omega-3 fatty acids can inhibit the activity of DGAT-2. A significant increase of the total PUFA $n-3$ in both soy diets, compared to casein, is observed in our model.

CPT-1 is an enzyme that catalyzes the ingress of fatty acids into the mitochondria for subsequent oxidation, and can be regulated by PPAR $\alpha$. The regulatory action of PPAR $\alpha$ is on lipid metabolism that acts on the uptake, the activation and the mitochondrial/peroxisomal $\beta$-oxidation of fatty acids [32] [33]. Considering these two genes (CPT-1 and PPAR $\alpha$ ), we observed that in normocaloric diets, soy flour compared to casein exerts a positive control on fatty acids transport into the mitochondria and could favor their catabolism. This effect is supported by the higher expression of PPAR $\alpha$. The bigger expression of both genes could be attributed to the higher content of unsaturated fatty acids supplied by the soy diet. On the other hand, the lower expression of CPT-1 and PPAR $\alpha$ in HS compared to CS can be attributed to the higher content of saturated fatty acids in the HS diet, which exerts an inhibitory effect on the mentioned genes. Sampath and Ntambi [34] reported that the changes in the fatty acids saturation status were implicated in the process of down-regulation of genes involved in fatty acids oxidation.

The diet fatty acids composition is known to influence the fatty acid composition of stored and structural lipids in the body [35] [36].

In the analysis of the fatty acids profile in liver of rats fed with soybean flour, compared to those fed with casein, we found a favorable unsat: sat ratio. This allows us to assume that soybean flour, even in hypercaloric diets, would have a positive effect on the prevention of simple steatosis or non-alcoholic steatohepatitis [37]. In addition, respect to polyunsaturated fatty acids a lower omega-6:omega-3 ratio was observed in the soy diet groups compared to the casein groups; thus, exerting a positive effect in preventing many diseases, including: cardiovascular disease, inflammatory and autoimmune diseases [38]. On the other hand, the flavonoids present in soy flour act synergistically with omega-3 fatty acids exert an anti inflammatory effect [39] [40].

In a liver histological study, Ascencio et al. [27] observed that rats fed with casein or casein high fat diets presented an increase in the number of oil droplets in the liver compared with rats fed with soy protein or soy protein high fat diets. We saw that soybean flour decreased fat deposits when compared to casein; and if we consider that the major portion of those deposits is due to the hepatic content of triglycerides, these data are consistent with the biochemical and molecular results showed in this study.

\section{Conclusions}

Under our experimental conditions, we can conclude that in animals that are being fed with a casein based normocaloric diet, replacing it with whole grain soybean flour exerts a protective effect on hepatic triglyceride deposition and improves the fatty acid profile. This behavior was also observed in hypercaloric diets, although in less extent.

We believe that consumption of soybean flour (whole grain) is a very good dietary resource for improving hepatic triglyceride deposits and fatty acid profile, and therefore, it has a beneficial health effect. 


\section{Acknowledgements}

This work was fully supported by the research project 8104 "Cellular alterations induced by nutritional, hormonal and environmental factors". Department of Biochemistry and Biological Sciences, Faculty of Chemistry, Biochemistry and Pharmacy, National University of San Luis, San Luis, Argentina.

\section{References}

[1] Akiyama, T., Tachibana, I., Shirohara, H., Watanabe, N. and Otsuki, M. (1996) High-Fat Hypercaloric Diet Induces Obesity, Glucose Intolerance and Hyperlipidemia in Normal Adult Male Wistar Rat. Diabetes Research and Clinical Practice, 31, 27-35. http://dx.doi.org/10.1016/0168-8227(96)01205-3

[2] Schlienger, J.L. and Pradignac, A. (2009) Nutrition Approaches to Prevent Chronic Disease. La Revue du Praticien, 59, 61-65.

[3] Sirtori, C.R., Galli, C., Anderson, J.W. and Arnoldi, A. (2009) Nutritional and Nutraceutical Approaches to Dyslipidemia and Atherosclerosis Prevention: Focus on Dietary Proteins. Atherosclerosis, 203, 8-17. http://dx.doi.org/10.1016/j.atherosclerosis.2008.06.019

[4] Barnes, S. (2004) Soy Isoflavones-Phytoestrogens and What Else? The Journal of Nutrition, 134, 1225S-1228S.

[5] de Meijer, V.E., Le, H.D., Meisel, J.A., Akhavan Sharif, M.R., Pan, A., Nosé, V. and Puder, M. (2010) Dietary Fat Intake Promotes the Development of Hepatic Steatosis Independently from Excess Caloric Consumption in a Murine Model. Metabolism, 59, 1092-1105. http://dx.doi.org/10.1016/j.metabol.2009.11.006

[6] Shimano, H., Yahagi, N., Amemiya-Kudo, M., Hasty, A.H., Osuga, J., Tamura, Y., Shionoiri, F., Iizuka, Y., Ohashi, K., Harada, K., Gotoda, T., Ishibashi, S. and Yamada, N. (1999) Sterol Regulatory Element-Binding Protein-1 as a Key Transcription Factor for Nutritional Induction of Lipogenic Enzyme Genes. The Journal of Biological Chemistry, 274, 35832-35839. http://dx.doi.org/10.1074/jbc.274.50.35832

[7] Shimomura, I., Bashmakov, Y., Ikemoto, S., Horton, J.D., Brown, M.S. and Goldstein, J.L. (1999) Insulin Selectively Increases SREBP-1c mRNA in the Livers of Rats with Streptozotocin-Induced Diabetes. Proceedings of the National Academy of Sciences of the United States of America, 96, 13656-13661. http://dx.doi.org/10.1073/pnas.96.24.13656

[8] Kersten, S., Seydoux, J., Peters, J.M., Gonzalez, F.J., Desvergne, B. and Wahli, W. (1999) Peroxisome Proliferator-Activated Receptor $\alpha$ Mediates the Adaptive Response to Fasting. The Journal of Clinical Investigation, 103, 14891498. http://dx.doi.org/10.1172/JCI6223

[9] Reeves, P.G., Nielsen, F.H. and Fahey Jr., G.C. (1993) AIN-93 Purified Diets for Laboratory Rodents: Final Report of the American Institute of Nutrition Ad Hoc Writing Committee on the Reformulation of the AIN-76A Rodent Diet. The Journal of Nutrition, 123, 1939-1951.

[10] Yang, B., Chen, L., Qian, Y., Triantafillou, J.A., McNulty, J.A., Carrick, K., Clifton, L.G., Han, B., Geske, R., Strum, J., Brown, K.K., Stimpson, S.A. and Pahel, G. (2006) Changes of Skeletal Muscle Adiponectin Content in Diet-Induced Insulin Resistant Rats. Biochemical and Biophysical Research Communications, 341, 209-217. http://dx.doi.org/10.1016/i.bbrc.2005.12.172

[11] Hara, A. and Radin, N.S. (1978) Lipid Extraction of Tissues with a Low-Toxicity Solvent. Analytical Biochemistry, 90, 420-426. http://dx.doi.org/10.1016/0003-2697(78)90046-5

[12] Folch, J., Lees, M. and Sloane Stanley, G.H. (1957) A Simple Method for the Isolation and Purification of Total Lipides from Animal Tissues. The Journal of Biological Chemistry, 226, 497-509.

[13] Sardesai, V.M. and Manning, J.A. (1968) Determination of Triglycerides in Plasma and Tissues. Clinical Chemistry, 14, 156-161.

[14] Layne, E. (1957) Spectrophotometric and Turbidimetric Methods for Measuring Proteins. In: Colowick, P.S. and Kaplan, N.O., Eds., Method in Enzymology, Academic Press, Inc., New York, 447-454. http://dx.doi.org/10.1016/s0076-6879(57)03413-8

[15] Marra, C.A. and de Alaniz, M.J. (1989) Influence of Testosterone Administration on the Biosynthesis of Unsaturated Fatty Acids in Male and Female Rats. Lipids, 24, 1014-1019. http://dx.doi.org/10.1007/BF02544071

[16] Yamamoto, K., Shibahara, A., Nakayama, T. and Kajimoto, G. (1991) Determination of Double-Bond Positions in Methylene-Interrupted Dienoic Fatty Acids by GC-MS as Their Dimethyl Disulfide Adducts. Chemistry and Physics of Lipids, 60, 39-50. http://dx.doi.org/10.1016/0009-3084(91)90013-2

[17] Snedecor, G.W. and Cochran, W.G. (1980) Statistical Methods. 7th Edition, Iowa State University Press, Ames.

[18] Biesalski, H.K., Erdman Jr., J.W., Hathcock, J., Ellwood, K., Beatty, S., Johnson, E., Marchioli, R., Lauritzen, L., Rice, H.B., Shao, A. and Griffiths, J.C. (2013) Nutrient Reference Values for Bioactives: New Approaches Needed? A Conference Report. European Journal of Nutrition, 52, 1-9. http://dx.doi.org/10.1007/s00394-013-0503-0 
[19] Buettner, R., Scholmerich, J. and Bollheimer, L.C. (2007) High-Fat Diets: Modeling the Metabolic Disorders of Human Obesity in Rodents. Obesity, 15, 798-808. http://dx.doi.org/10.1038/oby.2007.608

[20] Al-Dwairi, A., Pabona, J.M., Simmen, R.C. and Simmen, F.A. (2012) Cytosolic Malic Enzyme 1 (ME1) Mediates High Fat Diet-Induced Adiposity, Endocrine Profile, and Gastrointestinal Tract Proliferation-Associated Biomarkers in Male Mice. PLoS ONE, 7, e46716. http://dx.doi.org/10.1371/journal.pone.0046716

[21] Torre-Villalvazo, I., Tovar, A.R., Ramos-Barragán, V.E., Cerbón-Cervantes, M.A. and Torres, N. (2008) Soy Protein Ameliorates Metabolic Abnormalities in Liver and Adipose Tissue of Rats Fed a High Fat Diet. The Journal of Nutrition, 138, 462-468.

[22] Takahashi, Y. and Ide, T. (2008) Effects of Soy Protein and Isoflavone on Hepatic Fatty Acid Synthesis and Oxidation and mRNA Expression of Uncoupling Proteins and Peroxisome Proliferator-Activated Receptor Gamma in Adipose Tissues of Rats. The Journal of Nutritional Biochemistry, 19, 682-693. http://dx.doi.org/10.1016/j.jnutbio.2007.09.003

[23] Li, J.J., Huang, C.J. and Xie, D. (2008) Anti-Obesity Effects of Conjugated Linoleic Acid, Docosahexaenoic Acid, and Eicosapentaenoic Acid. Molecular Nutrition and Food Research, 52, 631-645. http://dx.doi.org/10.1002/mnfr.200700399

[24] Grundy, S.M. and Abrams, J.J. (1983) Comparison of Actions of Soy Protein and Casein on Metabolism of Plasma Lipoproteins and Cholesterol in Humans. The American Journal of Clinical Nutrition, 38, 245-252.

[25] Duane, W.C. (1999) Effects of Soybean Protein and Very Low Dietary Cholesterol on Serum Lipids, Biliary Lipids, and Fecal Sterols in Humans. Metabolism, 48, 489-494. http://dx.doi.org/10.1016/S0026-0495(99)90109-9

[26] Crouse III, J.R., Morgan, T., Terry, J.G., Ellis, J., Vitolins, M. and Burke, G.L. (1999) A Randomized Trial Comparing the Effect of Casein with That of Soy Protein Containing Varying Amounts of Isoflavones on Plasma Concentrations of Lipids and Lipoproteins. Archives of Internal Medicine, 159, 2070-2076. http://dx.doi.org/10.1001/archinte.159.17.2070

[27] Ascencio, C., Torres, N., Isoard-Acosta, F., Gómez-Pérez, F.J., Hernández-Pando, R. and Tovar, A.R. (2004) Soy Protein Affects Serum Insulin and Hepatic SREBP-1 mRNA and Reduces Fatty Liver in Rats. The Journal of Nutrition, 134, 522-529.

[28] Olofsson, S.O. and Boren, J. (2005) Apolipoprotein B: A Clinically Important Apolipoprotein Which Assembles Atherogenic Lipoproteins and Promotes the Development of Atherosclerosis. Journal of Internal Medicine, 258, 395-410. http://dx.doi.org/10.1111/j.1365-2796.2005.01556.x

[29] Xiao, C.W., Wood, C., Huang, W., L’Abbé, M.R., Gilani, G.S., Cooke, G.M. and Curran, I. (2006) Tissue-Specific Regulation of Acetyl-CoA Carboxylase Gene Expression by Dietary Soya Protein Isolate in Rats. British Journal of Nutrition, 95, 1048-1054. http://dx.doi.org/10.1079/BJN20061776

[30] Shukla, A., Brandsch, C., Bettzieche, A., Hirche, F., Stangl, G.I. and Eder, K. (2007) Isoflavone-Poor Soy Protein Alters the Lipid Metabolism of Rats by SREBP-Mediated Down-Regulation of Hepatic Genes. The Journal of Nutritional Biochemistry, 18, 313-321. http://dx.doi.org/10.1016/j.jnutbio.2006.05.007

[31] Rustan, A.C., Nossen, J.O., Christiansen, E.N. and Drevon, C.A. (1988) Eicosapentaenoic Acid Reduces Hepatic Synthesis and Secretion of Triacylglycerol by Decreasing the Activity of Acyl-Coenzyme A:1,2-Diacylglycerol Acyltransferase. Journal of Lipid Research, 29, 1417-1426.

[32] Mezei, O., Banz, W.J., Steger, R.W., Peluso, M.R., Winters, T.A. and Shay, N. (2003) Soy Isoflavones Exert Antidiabetic and Hypolipidemic Effects through the PPAR Pathways in Obese Zucker Rats and Murine RAW 264.7 Cells. The Journal of Nutrition, 133, 1238-1243.

[33] Morifuji, M., Sanbongi, C. and Sugiura, K. (2006) Dietary Soya Protein Intake and Exercise Training Have an Additive Effect on Skeletal Muscle Fatty Acid Oxidation Enzyme Activities and mRNA Levels in Rats. British Journal of Nutrition, 96, 469-475.

[34] Sampath, H. and Ntambi, J.M. (2004) Polyunsaturated Fatty Acid Regulation of Gene Expression. Nutrition Reviews, 62, 333-339. http://dx.doi.org/10.1111/j.1753-4887.2004.tb00058.x

[35] Kassem, A.A., Abu Bakar, M.Z., Yong Meng, G. and Mustapha, N.M. (2012) Dietary (n-6:n-3) Fatty Acids Alter Plasma and Tissue Fatty Acid Composition in Pregnant Sprague Dawley Rats. The Scientific World Journal, 2012, Article ID: 851437. http://dx.doi.org/10.1100/2012/851437

[36] Mohamed, A.I., Hussein, A.S., Bhathena, S.J. and Hafez, Y.S. (2002) The Effect of Dietary Menhaden, Olive, and Coconut Oil Fed with Three Levels of Vitamin E on Plasma and Liver Lipids and Plasma Fatty Acid Composition in Rats. The Journal of Nutritional Biochemistry, 13, 435-441. http://dx.doi.org/10.1016/S0955-2863(02)00196-1

[37] Gentile, C.L. and Pagliassotti, M.J. (2008) The Role of Fatty Acids in the Development and Progression of Nonalcoholic Fatty Liver Disease. The Journal of Nutritional Biochemistry, 19, 567-576. http://dx.doi.org/10.1016/j.jnutbio.2007.10.001

[38] Simopoulos, A.P. (2008) The Importance of the Omega-6/Omega-3 Fatty Acid Ratio in Cardiovascular Disease and 
Other Chronic Diseases. Experimental Biology and Medicine, 233, 674-768. http://dx.doi.org/10.3181/0711-MR-311

[39] Nakagawa, H., Yamamoto, D., Kiyozuka, Y., Tsuta, K., Uemura, Y., Hioki, K., Tsutsui, Y. and Tsubura, A. (2000) Effects of Genistein and Synergistic Action in Combination with Eicosapentaenoic Acid on the Growth of Breast Cancer Cell Lines. The Journal of Cancer Research and Clinical Oncology, 126, 448-454. http://dx.doi.org/10.1007/s004320050012

[40] Ward, W.E. and Fonseca, D. (2007) Soy Isoflavones and Fatty Acids: Effects on Bone Tissue Postovariectomy in Mice. Molecular Nutrition and Food Research, 51, 824-831. http://dx.doi.org/10.1002/mnfr.200600187

\section{List of Abbreviations}

ACC Acetyl-CoA Carboxylase

AIN-93 American Institute of Nutrition 1993

ANOVA One-Way Analysis of Variance

Apo B Apolipoprotein B

AU Arbitrary Units

CC Control Casein

c-GLC Capillary Gas-Liquid Chromatography

CPT-1 Carnitine Palmitoyltransferase 1

CS Control Soy

DGAT-2 Diacylglycerol Acyltransferase 2

DHA Docosahexaenoic Acid

EPA Eicosapentaenoic Acid

FAME Fatty Acid Methyl Esters

FAS Fatty Acid Synthase

HC Hypercaloric Casein

HS Hypercaloric Soy

LDL Low Density Lipoprotein

mGPAT Mitochondrial Glycerol-3-Phosphate Acyltransferase

PPAR $\alpha \quad$ Peroxisome Proliferator-Activated Receptors Alpha

PUFA $n$-3 Omega-3 Polyunsaturated Fatty Acids

PUFA $n-6$ Omega-6 Polyunsaturated Fatty Acids

RT-PCR Reverse Transcription Polymerase Chain Reaction

SREBP-1c Sterol-Regulatory Element-Binding Protein 1c

TG Triglycerides

TLC Thin-Layer Chromatography

VLDL Very Low Density Lipoprotein 